\title{
Aleksandr Konstantinovin harkitusti täydennetty
} tila

Viime vuonna edesmennyt Aleksandr Konstantinov (1954-2019) oli yksi kansainvälisesti huomattavimmista kaljuista venäläisistä nykytaiteilijoista. Kansainvälisyys on nykytaiteen vakio, mutta harva venäläinen nykytaiteilija on onnistunut luomaan yhtä huomattavaa taiteellista perintöä Venäjän ulkopuolella. Koulutukseltaan hän oli matemaatikko ja toimi Moskovan elektroniikan ja matematiikan instituutin professorina ennen liittymistään vuonna 1987 Eremitaasi-nimiseen underground-taiteilijoiden ryhmään. Hänen ensimmäinen yksityisnäyttelynsäjärjestettiin vuonna 1992 Tretjakovin galleriassa. Konstantinovin varhaistuo-

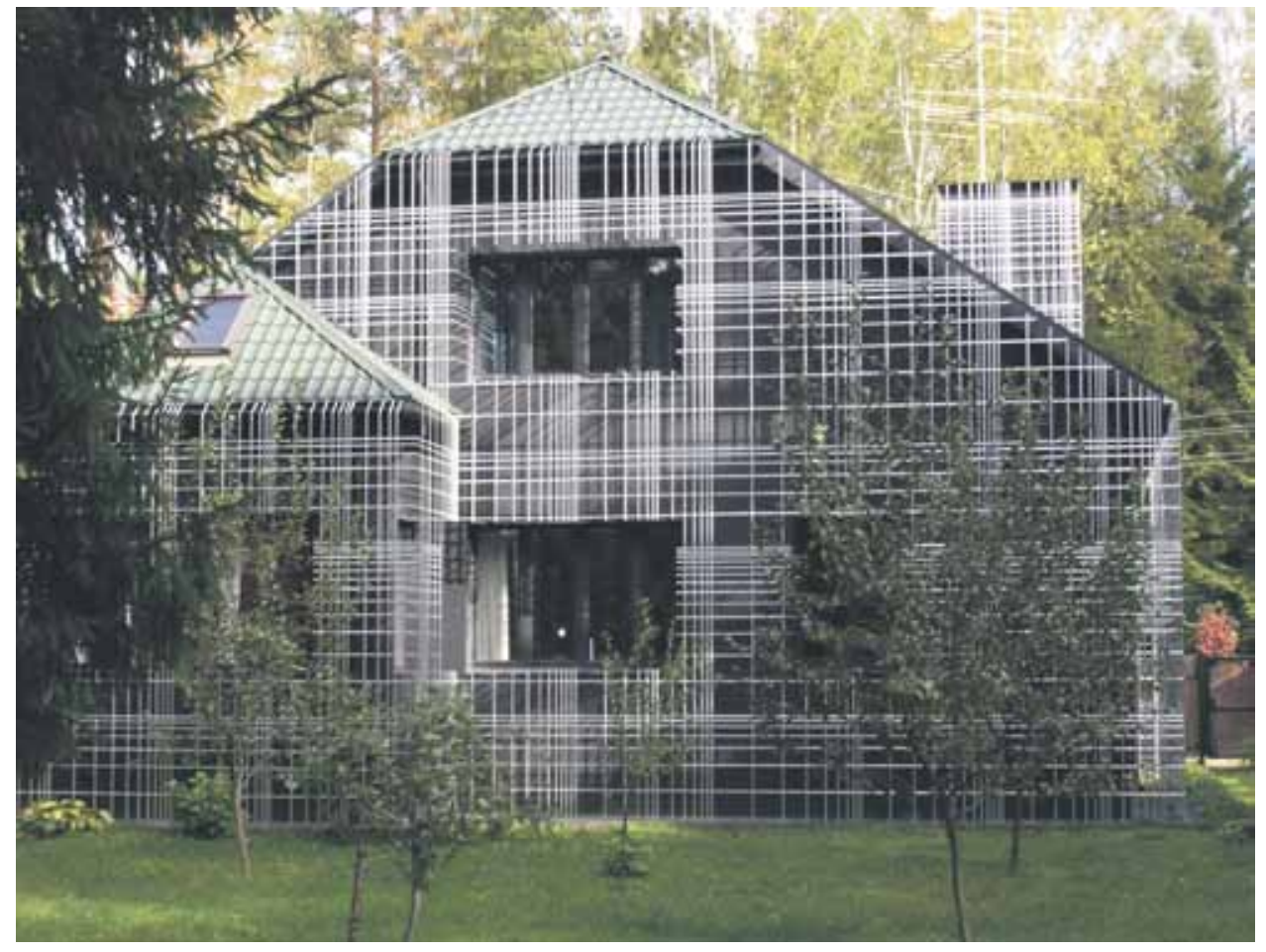

Alumiinitalo, Moskovan alue, 2008. 
tanto koostuu pitkälti konseptualistisesta grafiikasta. Sittemmin hän livahti vaivihkaa ulos näyttelysaleista tilataiteen pariin, josta hänet muistetaan parhaiten.

Konstantinovin tuotanto liikkuu jossakin installaation, arkkitehtuurin, muotoilun ja maataiteen välimaastossa. Itse hän on todennut vain astuneensa ulkoilmaan pikku piirustusten kanssa. Ne muistuttavatkin grafiikkaa, jossa samat muodot ja värit toistuvat kolmiulotteisessa ympäristössä. Konstantinovin varhaiset tilataideteokset olivat väliaikaisia installaatioita. Yhtymäkohtia voi halutessaan löytää vaikkapa Daniel Burenin tai Christon ja Jeanne-Clauden taiteilijaduon tuotannon kanssa. Myöhemmin monista Konstantinovin rakennelmista on tullut pysyviä kohteita. Installaatioiden ohella hän on suunnitellut lukuisia puistoja, puolijulkisia tiloja ja asuinrakennuksia. Suuri osa niistä sijaitsee Venäjän ulkopuolella. Eräässä haastattelussaan vuonna 2008 Konstantinov totesi:

Lukeudun niihin ihmisiin, jotka suhtautuvat historiaan suurella kunnioituksella. Kaikki mikä on mahdollista säilyttää, on säilytettävä. Kaikin keinoin, kaikin voimin - jopa silloin, kun kyseessä ei ole mikään arkkitehtuurin merkkipaalu. Venäjällä on riittävästi tyhjää tilaa, jonne rakentaa. Miksi tunkeutua kaupunkien sisälle? Varsinkin Moskova on tässä suhteessa katastrofi - sellaista hävitystä ei nähty edes vallankumouksen tai Neuvostoliiton aikana. Ei ole lainkaan välttämätöntä tuhota, jotta voisi rakentaa.

Kenties siksi, että Konstantinovista tuli ammattitaiteilija vasta myöhemmällä iällä, hänen tuotannostaan puuttuu tyystin tietynlainen nuorekas uho ja radikaalisuus, joka on romantiikan päivistä lähtien ollut taidemaailman normi. Sen sijaan hänen teoksensa täydentävät todellisuutta harkitusti ja tekevät ympäristöstään hienovaraisesti merkityksellisempiä. Nyt kun taiteilijasta on aika jättänyt, odottaa hänen tuotantonsa historiallista käsittelyä.

Teksti: Mika Pylsy Kuvat: (C) Aleksandr Konstantinov

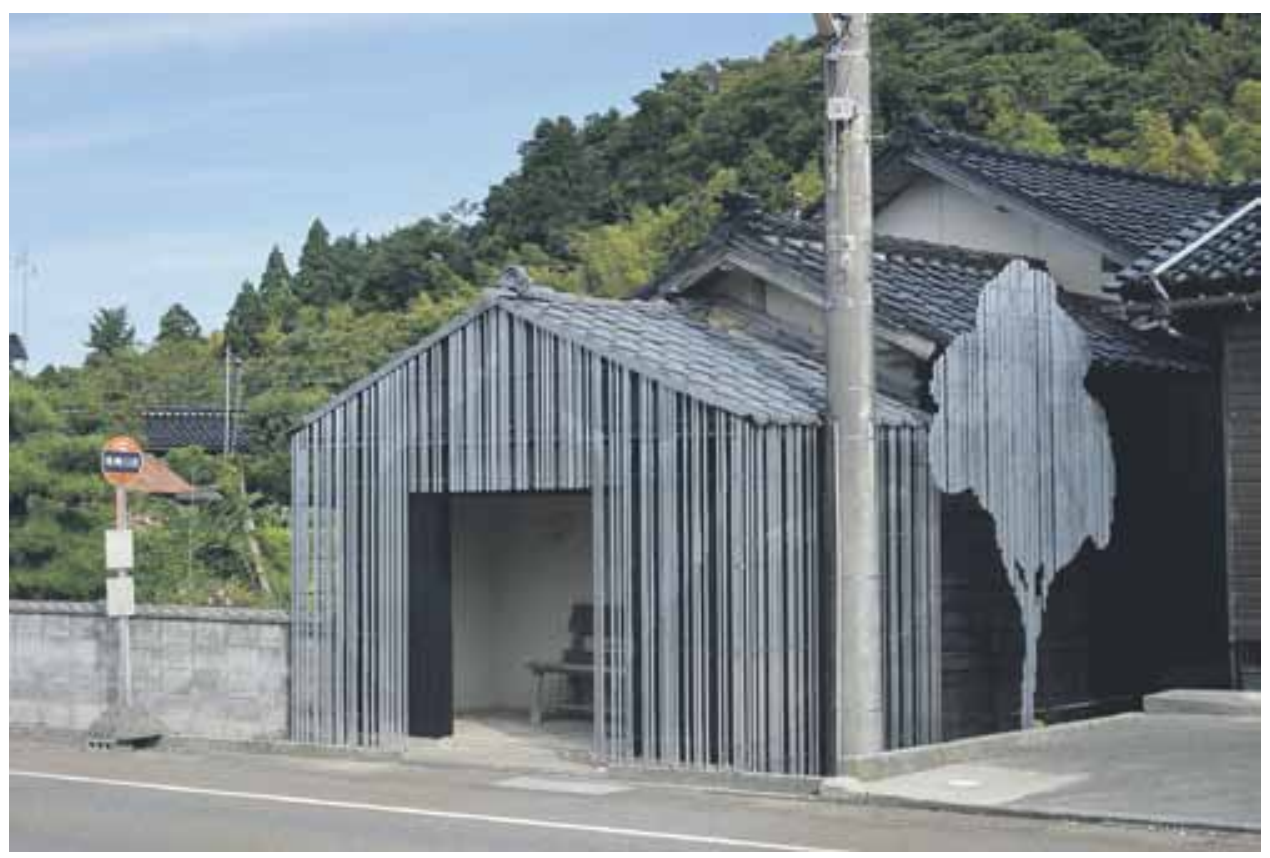

Bussipysäkki nro. 2, Suzu, Japani, 2017. 


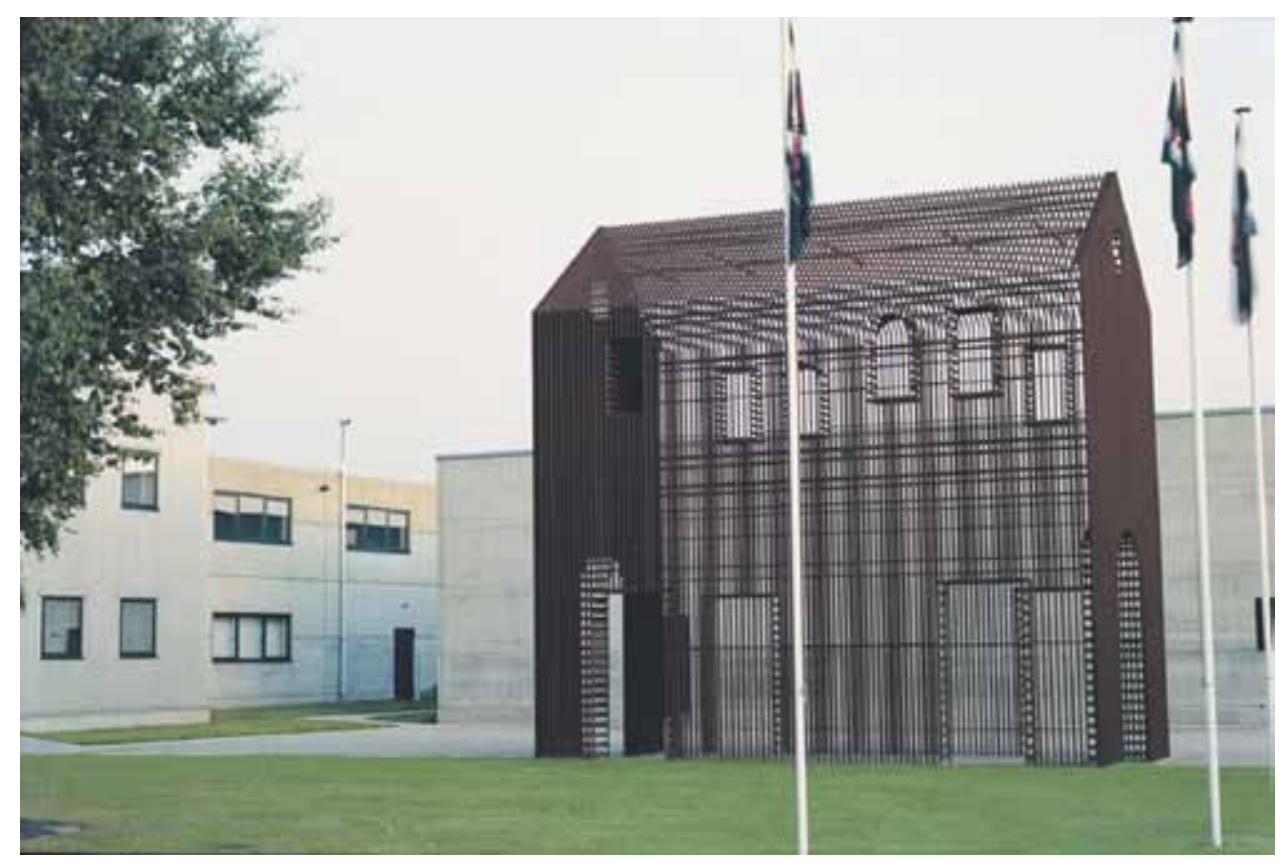

Ironia, Nieuwerkerken, Belgia, 2009.

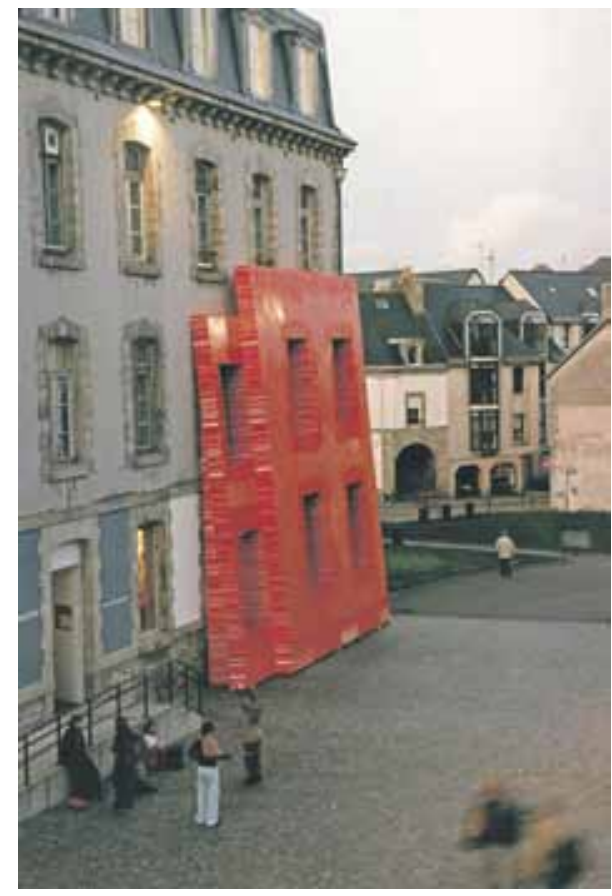

Kortteli, Centre for Contemporary Arts, Quimper, Ranska. 2006

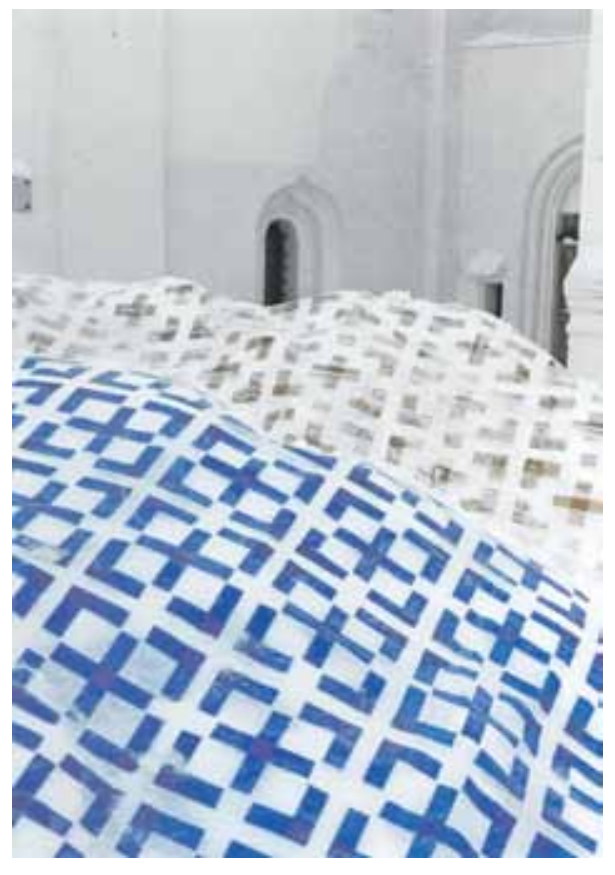

Peite, Ferapontovo, Vologda, Venäjä, 2003. 


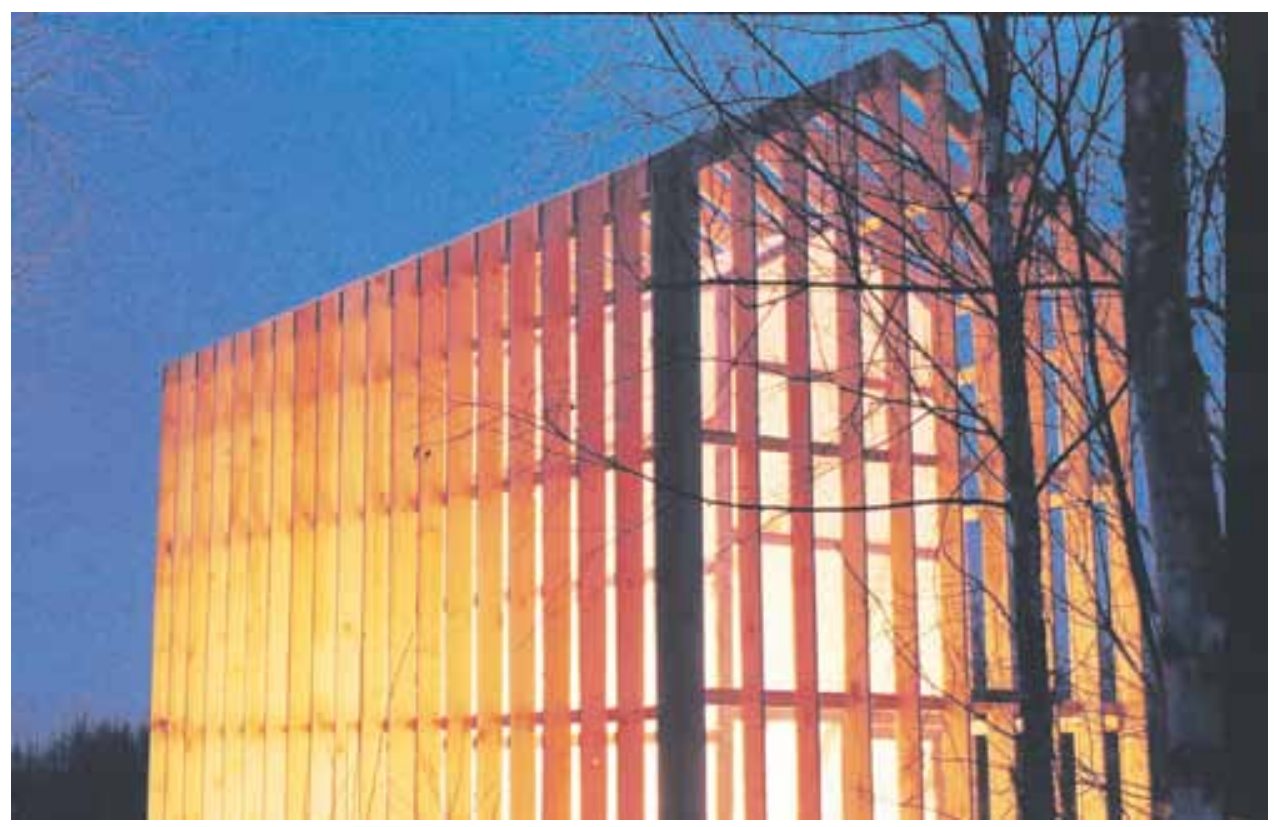

Mökki. Basilika, Arkstojanie-festivaali, Nikola-Lenivets, Kalugan alue, Venäjä. 2008.

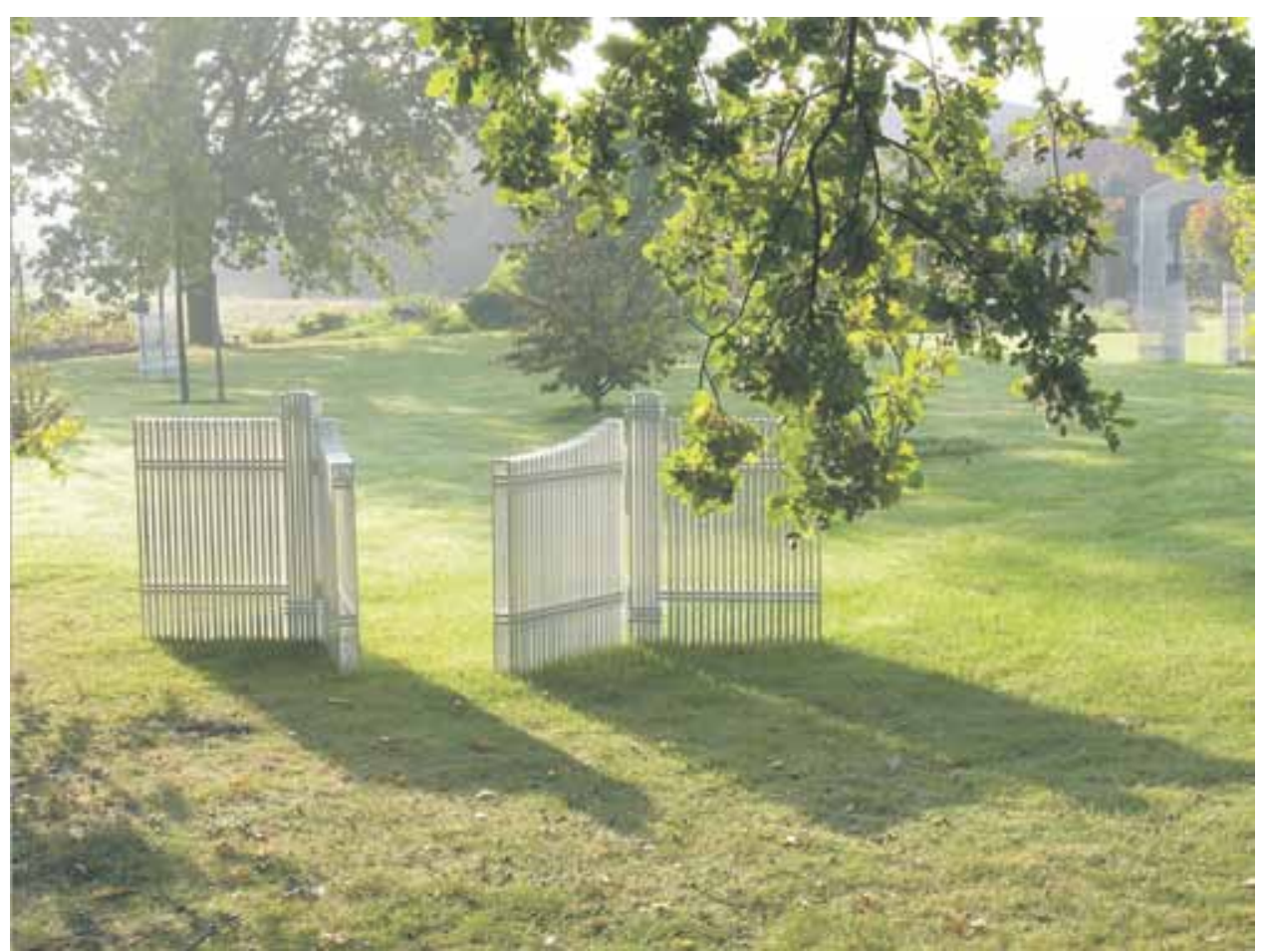

Portit, Veistosnäyttely, Haag, Alankomaat, 2013. 


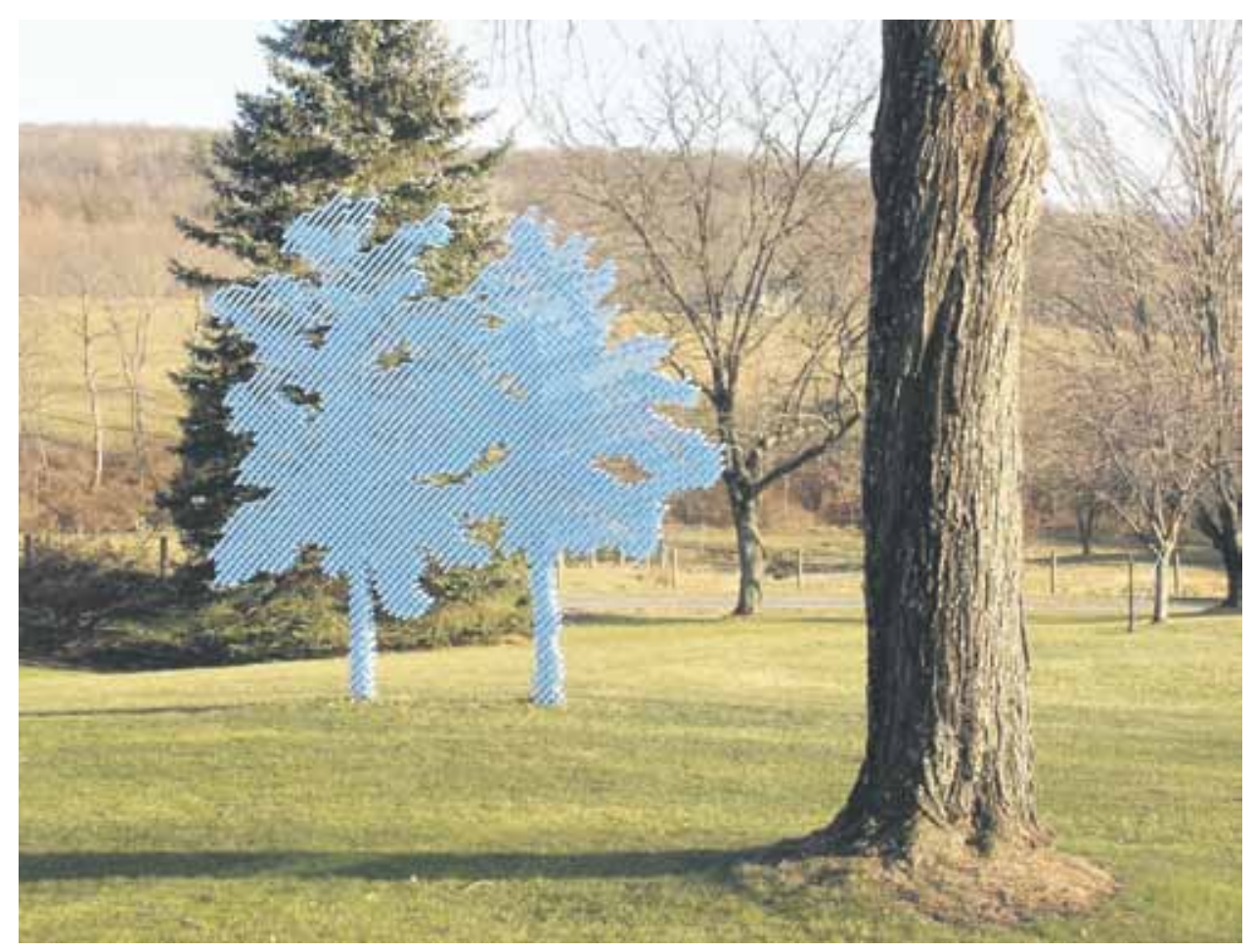

Siniset puut, New York, Yhdysvallat, 2011.

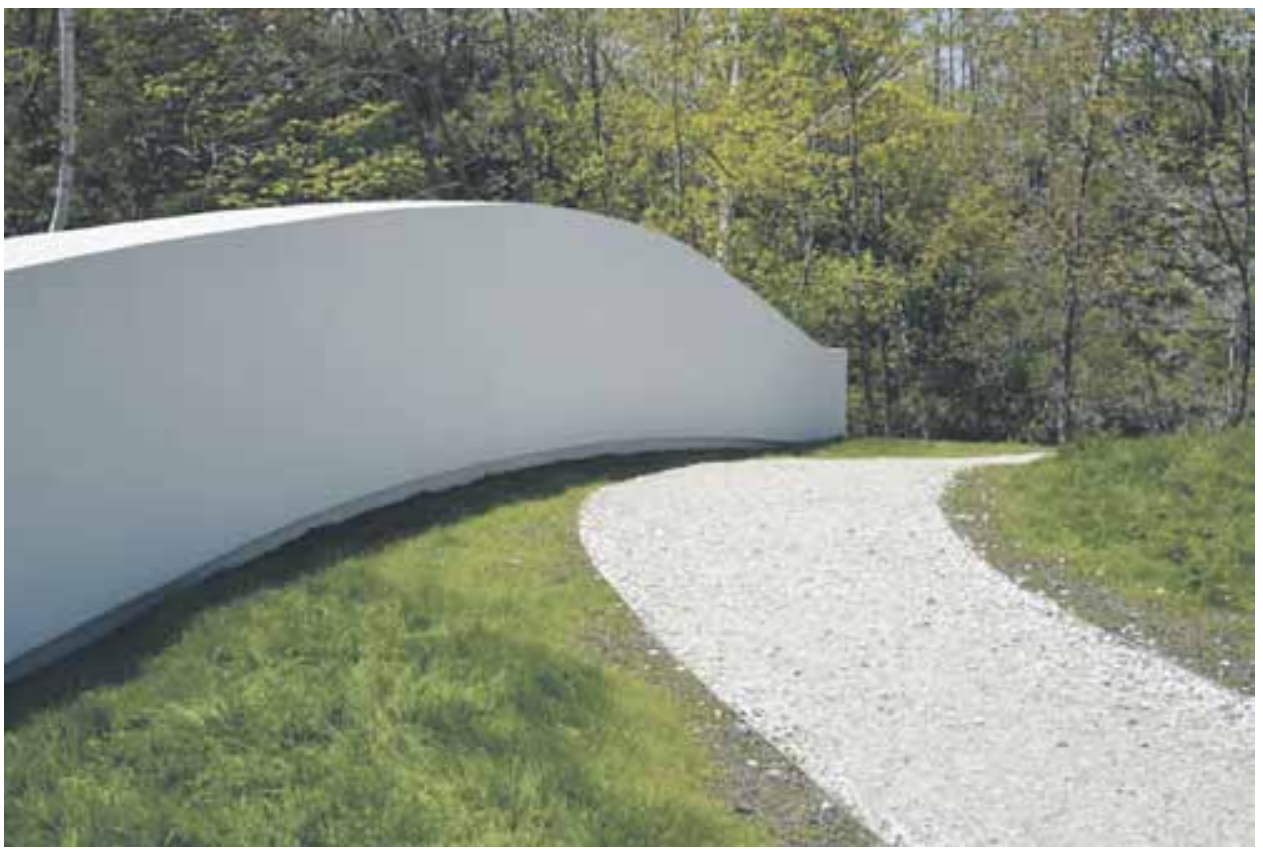

TurnPark, West Stockbridge, MA, Yhdysvallat, 2013-2017. 


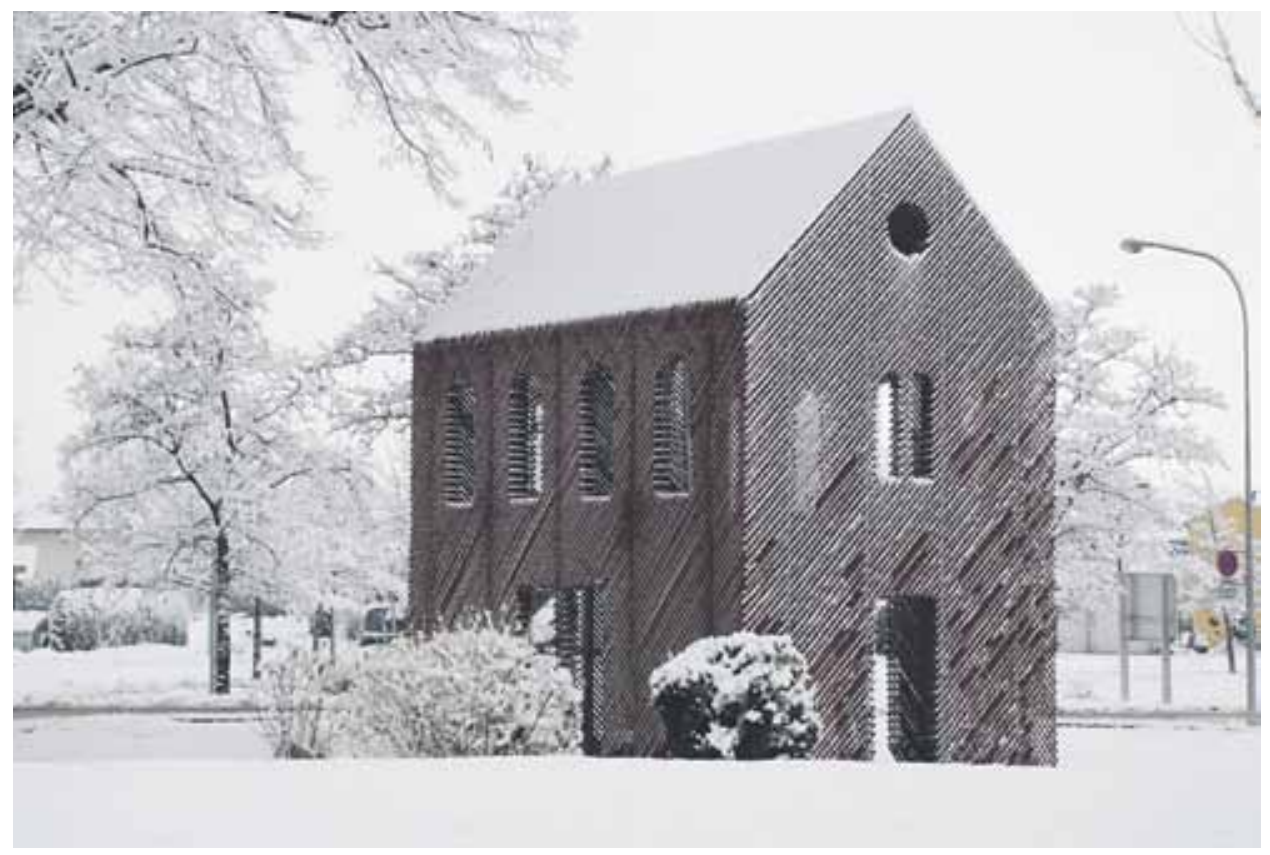

Unter de Linde, Otten Kunst Raum, Hohenems, Itävälta. 2008.

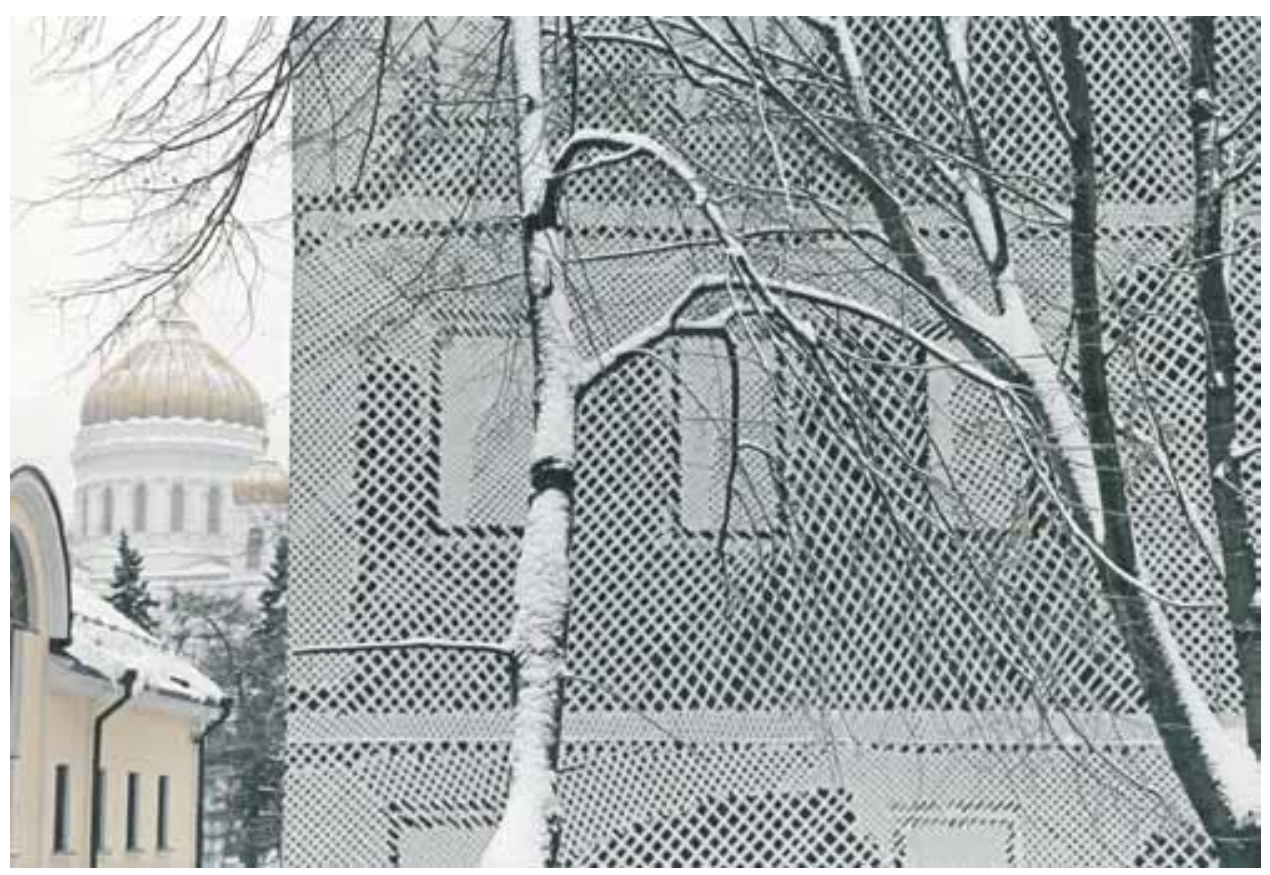

Valkoinen kortteli, Puškinin museo, Moskova, 2005-2006. 


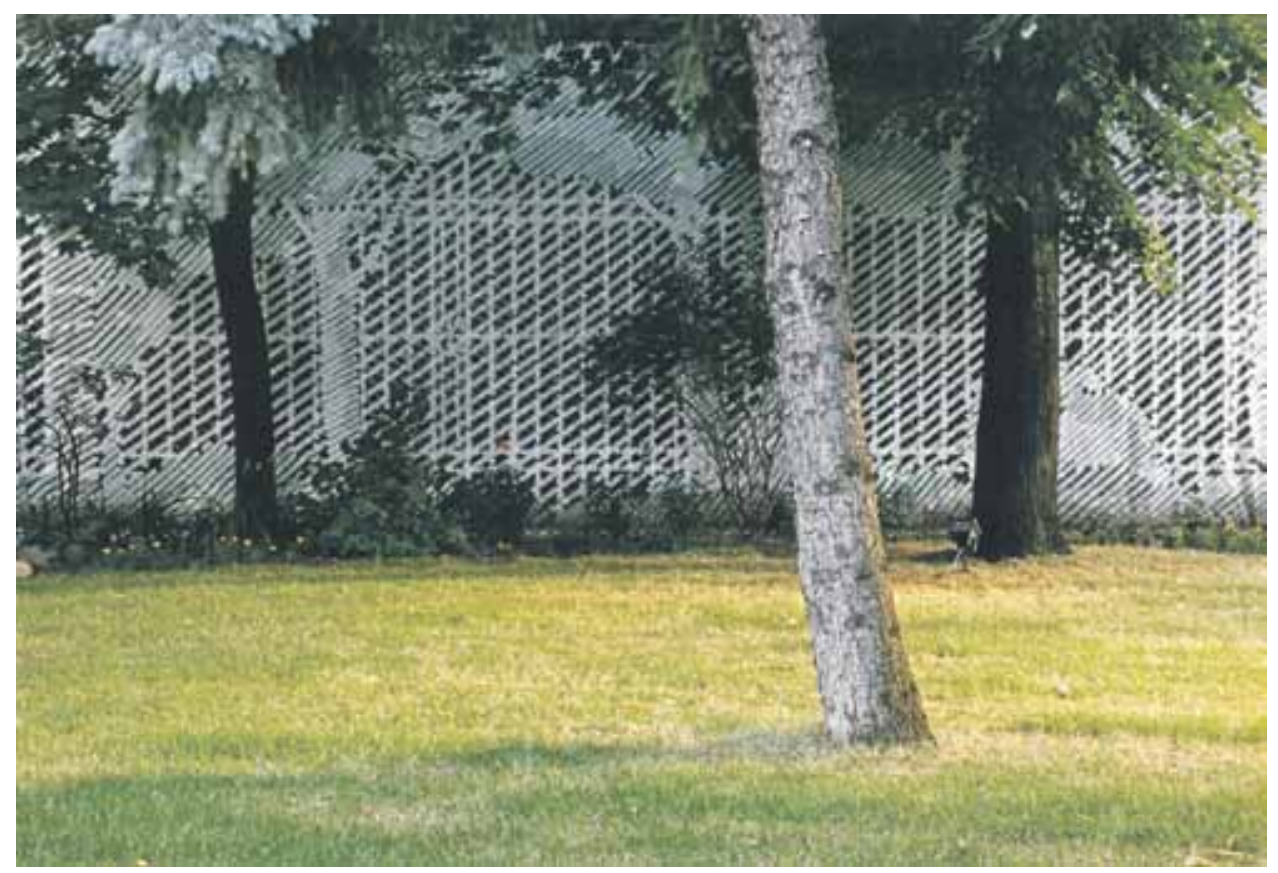

Luxembourgin puisto, Luxembourgin suurlähetystön puisto, Moskova, Venäjä 2005. 